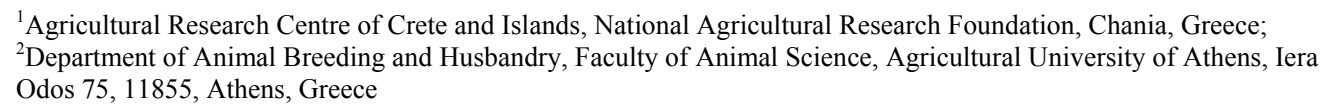
MANOUSOS VOLANIS ${ }^{1}$, ANTONIOS KOMINAKIS $^{2 *}$ and EMMANOUEL ROGDAKIS ${ }^{2}$

\title{
Genetic analysis of udder score and milk traits in test day records of Sfakia dairy ewes
}

\author{
Dedicated to Prof. Drs. h. c. Franz Pirchner PhD, on the occasion of his $75^{\text {th }}$ birthday
}

\begin{abstract}
Summary
A total of 4466 monthly test day records of 555 Greek Sfakia dairy ewes were used to estimate heritabilities as well as genetic and phenotypic correlations for udder score (US), average daily milk yield (MY), fat percentage (FC) and protein percentage (PC) of milk. Genetic parameters were estimated with a multitrait animal model with correlated residuals. Heritabilities were between 0.17 and $0.24,0.41$ and $0.47,0.32$ and 0.52 and 0.44 and 0.55 , for test day US, MY, FC and PC, respectively. Within traits, genetic correlations between test days were between 0.54 and $0.57,0.71$ and $0.96,0.79$ and 0.99 and 0.85 and 0.99 for US, MY, FC and PC, respectively. Genetic correlations between milk traits and US were negative and of very low magnitude $(-0.04$ to -0.06$)$. Genetic correlations between MY - FC and MY - PC were negative and of varying magnitude, from - 0.37 to 0.52 and from -0.44 to -0.50 , in the four test days, respectively. Fat and protein percentages were found to be highly, positively, correlated.
\end{abstract}

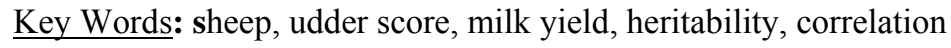

\section{Zusammenfassung}

Titel der Arbeit: Genetische Analyse von Euterform und Milchmerkmalen anhand der Testtagsdaten beim Sfakia Milchschaf

Heritabilitäten sowie genetische und phänotypische Korrelationen der Euterform (US), der Tagsmilchmenge (MY), des Fettgehalts (FC) und des Eiweißgehalts (PC) wurden anhand von 4466 monatlichen Testtagsdaten von 555 Sfakia Milchschafen untersucht. Die genetischen Parameter wurden mit einem Multivariat-Tiermodell mit korrelierten Resten geschätzt. Heritabilitätswerte zwischen den Testtagen betrugen zwischen 0,17 bis 0,24 für US, 0,41 bis 0,47 für MY, 0,32 bis 0,52 für FC und 0,44 bis 0,55 für FC. Die genetischen Korrelationen zwischen den Testtagen waren 0,54 bis 0,57 für US, 0,71 bis 0,96 für MY, 0,79 bis 0,99 für FC und 0,85 bis 0,99 für PC. Die genetischen Korrelationen zwischen der US und den verschiedenen Milchmerkmalen waren negativ und lagen nahe Null (-0,04 bis -0,06). Die genetischen Korrelationen zwischen MY und FC waren negativ und schwankten von $-0,37$ bis $-0,52$, während die entsprechenden Korrelationen zwischen MY und PC von $-0,44$ bis $-0,50$ variierten. Zwischen dem FC und dem PC wurden positive genetische Korrelationen festgestellt.

Schlüsselwörter: Schaf, Euterauswertung, Milchmenge, Heritabilität, Korrelation

\section{Introduction}

Findings of the late Minoan period $(1600-1450 \mathrm{BC})$, currently on display at the Archaeological Museum of Iraklion (Crete), represent a sheep showing clearly the typical characteristics of the Zackel type. According to PAPADOPOULOS (1936) this type of sheep has been retained unchanged through the centuries and is the common

\footnotetext{
* Corresponding author
} 
ancestor of all purebred sheep types kept in Crete, today. The most stable and homogenous type is a sheep kept in the wider area of Sfakia on the White Mountains and in the lower area of the Apokoroniou district. This sheep is known under the name Sfakia sheep. The animals are white colored with black dots around the eyes and legs. Ewes are hornless and rams bear horns. Adult ewes and rams have average heights 64 and $70 \mathrm{~cm}$ and average body weight 64 and $44 \mathrm{~kg}$, respectively (VOLANIS and TZERAKIS, 1997a). Data analysis of 2942 lactations, spanning years 1982 to 1990 , showed that the average milk yield and the length of the milking period is $109.8 \pm 40.8$ $\mathrm{kg}$ and $156.5 \pm 29.3$ days, respectively (VOLANIS and TZERAKIS, 1997c). Average birth weight, weaning weight (at $66 \pm 5$ days) and daily gain of lambs are $3.07 \pm 0.50$ $\mathrm{kg}, 13.56 \pm 2.98 \mathrm{~kg}$ and $162.8 \pm 40.1 \mathrm{~g}$, respectively (VOLANIS and TZERAKIS, 1997b).

A number of studies have investigated the relationships between udder conformation traits, milk yield and milk fractionation in dairy ewes on a phenotypic level (SAGI and MORAG, 1974; SAGI, 1978; LABUSSIERE et al., 1981; KUKOVICS et al., 1993; MAHLER and VRAYLA-ANESTI, 1994; FERNANDEZ et al., 1995). Udder morphology has been recognized as one of the main factors affecting the ability of machine milking of dairy ewes (LABUSSIERE, 1988; FERNANDEZ et al., 1995). The genetic basis of udder morphology and its genetic relationship with milk yield has also been investigated in some sheep breeds for dairy (GOOTWINE et al., 1980; CASU et al., 1989; FERNANDEZ et al., 1997; CARTA et al., 1998) and meet purpose (CHARON, 1990).

The stability of the Sfakia sheep under various keeping conditions, its relatively high productivity and the preference shown by the local producers, indicate the need of developing modern, consistent pure-breeding selection schemes for the breed. The design of efficient selection schemes presumes, however, that the genetic parameters of all important production traits of the population under examination are known. Aim of the present study was thus the estimation of genetic parameters for udder score and milk traits, i.e. milk yield, fat percentage, protein percentage, in an attempt to appraise the possibility of genetic improvement of the Sfakia dairy breed.

\section{Material and methods}

\section{Data}

Test day records $(\mathrm{n}=12358)$ for udder score (US), milk yield (MY), fat percentage (FC) and protein percentage (PC) from 1404 Sfakia dairy ewes were collected. The data originated from the experimental flock of the Agricultural Research Station in Assomate near Rethymno, Crete. Data and pedigree information spanned years from 1982 to 1990. Data edits involved, sire, dam, age of ewe, production year, test day number, US, MY, FC and PC at test day, lactation milk yield and the number of test day count. The first test day record was obtained on average 15 days after weaning, followed by three other monthly records. Udders were classified by the SAGI and MORAG's (1974) method of udder scoring. The method is based on the degree of differentiation of the two clusters and on the teat placement with respect to the lowest part of the cistern. In udders of Type I, teats are placed at a high level, with the respect to the lowest part of the cistern, while there is no differentiation between the left and the right cluster. In Type II, teats are placed at a high level, with respect to the lowest 
part of the cistern, while the two clusters are slightly differentiated. In type III, teats are placed lower, with respect to the lowest part of the cistern and the clusters are clearly differentiated. In type IV, teats are pointed downwards and the clusters are clearly differentiated. Almost sixty four percent (64\%) of the initial records were removed from the data using the following criteria: daily milk yield less than $80 \mathrm{~g}$, when sire and dam was unknown, less than 4 successive test day records per ewe and lactation. Most of the records, however, were excluded due to unknown pedigree structure and recording inconsistency. After this initial exclusion of records, the number of ewes with udder scores I $(n=24)$ and IV $(n=35)$ in the remaining data set was very small. Because of this reason, those records were excluded from the data. The final data set consisted of 4466 test day records of US, MY, FC and PC obtained from 555 Sfakia ewes. Two udder type classes (2 and 3), six lactation number classes, 1-6, three month lambing classes, January, November and December and two litter size classes, 1 and 2, were built. Furthermore, four test days were included, according to days in milk at test day: 10-20, 40-50, 70-80 and 100-110.

\section{Test of significance of environmental effects}

The mathematical model for analyzing the US, MY, FC and PC included the following fixed effects: lactation number by year, year by month, litter size, test day, nested in lactation number, as a linear and quadratic covariable and age of ewe at lactation as a linear and quadratic covariable. The importance of the various environmental effects was determined by least squares analysis of variance. Since udder score is a categorical trait test of significance was performed by the CATMOD procedure (SAS, 1992). Analysis of variance of milk traits was performed by the GLM procedure (SAS, 1992).

\section{Parameter estimation}

Genetic parameters for US, MY, FC and PC were estimated by multitrait $(n=4)$ analysis applying an animal model with animal's additive genetic effect as the only random effect and with correlated residuals because of repeated records per animal. The fixed effects part of the model included the effects found statistically significant for the traits in the previous test. (Co)variance components as well as standard errors of estimates were estimated by a derivate-free algorithm using the DFREML computer program (MEYER, 1997).

\section{Results and discussion}

\section{Descriptive statistics}

Means and standard deviations for test day and lactation US, MY, FC and PC are summarized in Table 1. Milk yield significantly declined from almost 1.0 to $0.64 \mathrm{~kg}$, at the beginning to the end of the testing period, respectively. FC gradually declined from first to third test day and was highest at the $4^{\text {th }}$ test day. PC increased consistently from $1^{\text {st }}$ to the $4^{\text {th }}$ test day. Furthermore, no significant differences were found in MYs and FCs between udders of type II and III (Table 2). On the contrary, udders of type III excreted milk with slightly higher protein percentages than udders of type II. Udders of type III outnumbered those of type II (Table 2). CASU et al., (1983) also found in Sarda sheep, that a large cistern with teats implanted at a relatively high level, with 
respect to the lowest part of the udder and forming a large angle with the vertical position was the most frequent udder type. Neither type II nor type III is ideal for machine milking (SAGI and MORAG, 1974; CASU et al., 1983; LABUSSIERE, 1988). During the time period examined (1982 - 1990) Sfakia ewes of the Experimental Station of Assomate were milked by hand; no significant differences in milk yield between types II and III could be thus expected (Table 2). In recent years, however, machine milking has been introduced in the Experimental Station and the need for machine-orientated udders is more evident. In machine milked Assaf (Awassi $\mathrm{x}$ East Friesian) ewes, SAGI and MORAG (1974) found lower milk yields as gland differentiation became less clear and teats were placed higher.

Table 1

Means $(\mu)$ and standard deviations (SD) for udder score (US), daily milk yield (MY), fat percentage (FC) and protein percentage (PC) in four test days and lactation in the Sfakia dairy sheep (Mittelwerte ( $\mu$ ) und Standardabweichungen (SD) der Euterform (US), der Milchmenge (MY), des Fettgehalts (FC) und des Eiweißgehalts (PC) an vier Testtagen beim Sfakia Milchschaf)

\begin{tabular}{|c|c|c|c|c|c|c|c|c|c|c|}
\hline \multirow[b]{3}{*}{ Trait } & \multicolumn{10}{|c|}{ Test day } \\
\hline & \multicolumn{2}{|c|}{1} & \multicolumn{2}{|c|}{2} & \multicolumn{2}{|c|}{3} & \multicolumn{2}{|c|}{4} & \multicolumn{2}{|c|}{ Lactation } \\
\hline & $\mu$ & $\mathrm{SD}$ & $\mu$ & $\mathrm{SD}$ & $\mu$ & SD & $\mu$ & SD & $\mu$ & SD \\
\hline US & $2.73^{\mathrm{a}}$ & 0.44 & $2.68^{b}$ & 0.47 & $2.78^{c}$ & 0.42 & $2.83^{d}$ & 0.38 & 2.75 & 0.43 \\
\hline MY (kg) & $1.03^{\mathrm{a}}$ & 0.32 & $0.96^{\mathrm{b}}$ & 0.32 & $0.82^{c}$ & 0.29 & $0.64^{\mathrm{d}}$ & 0.25 & 0.86 & 0.33 \\
\hline $\mathrm{FC}(\%)$ & $7.22^{\mathrm{a}}$ & 0.93 & $6.88^{b}$ & 0.86 & $6.85^{\mathrm{bc}}$ & 0.87 & $7.46^{\mathrm{d}}$ & 0.94 & 7.10 & 0.94 \\
\hline PC (\%) & $5.46^{\mathrm{a}}$ & 0.50 & $5.56^{\mathrm{b}}$ & 0.52 & $5.59^{b c}$ & 0.47 & $5.60^{\mathrm{bcd}}$ & 0.52 & 5.55 & 0.50 \\
\hline
\end{tabular}

Table 2

Means $(\mu)$ and standard deviations (SD) for daily milk yield (MY), fat percentage (FC) and protein percentage (PC) for the two udder scores (Mittelwerte $(\mu)$ und Standardabweichungen (SD) der Milchmenge (MY), des Fettgehalts (FC) und des Eiweißgehalts (PC) von zwei Eutertypen)

\begin{tabular}{ccccc}
\hline & \multicolumn{4}{c}{ Udder score } \\
\cline { 2 - 5 } Trait & $\mu$ & II $(\mathrm{n}=1097)$ & $\mu$ & III $(\mathrm{n}=3369)$ \\
MY $(\mathrm{kg})$ & $0.88^{\mathrm{a}}$ & 0.33 & $0.86^{\mathrm{a}}$ & 0.33 \\
FC $(\%)$ & $7.12^{\mathrm{a}}$ & 0.94 & $7.10^{\mathrm{a}}$ & 0.93 \\
PC $(\%)$ & $5.48^{\mathrm{a}}$ & 0.50 & $5.58^{\mathrm{b}}$ & 0.50 \\
\hline
\end{tabular}

Means with different letters as superscripts are statistically significant different $(\mathrm{p}<0.05)$

\section{Udder classification}

Methods of udder classification are also a major investigation area. CASU et al. (1983) proposed for the Sarda breed a modification of the SAGI and MORAG's method of udder classification which also included four scores based on the teat placement and the degree of differentiation of the two clusters. More recently, DE LA FUENTE et al. (1996) proposed a method of udder appraisal based on scoring five udder traits: udder depth, udder attachment, teat replacement (angle), teat size and udder shape on a ninepoint linear scale. CARTA et al. (1998) proposed a method of scoring the udders, on a linear scale, ranging from 1 to 7 points, which is also based on teat placement and the height of the cistern. The general idea behind the use of large scales in udder classification methods is that such a point system is more suited for genetic evaluations by BLUP when compared to categorical traits evaluation. While udder measurements, like cistern height, teat placement, teat angle and teat size, as early proposed by LABUSSIERE et al. (1981) are more objective measures for udder characterization, they are not feasible for large scaled classifications due to low speed 
and high labor costs. It therefore seems that methods of scoring udders globally will remain of some importance for large scaled classifications. In Sfakia breed, further research is needed to define the udder traits and linear scales for use as selection criteria for machine milkability.

\section{Genetic parameters}

Table 3 summarizes estimates of heritabilities, genetic and phenotypic correlations for US, MY, FC and PC for test day and lactation records. Heritability of US varied little by test day, from 0.17 to 0.24 . Although a clearly categorical trait, with only two categories (II and III) there was significantly high genetic variance detected for the trait by the REML methodology. Heritability of MY increased progressively from 0.41 to 0.45 in the later part of the testing period, while heritability of PC increased significantly in the second test day. Within traits, genetic correlations between test days were in the range from 0.54 to $0.57,0.71$ to $0.96,0.79$ to 0.99 and 0.85 to 0.99 , for US, MY, FC and PC, respectively. Phenotypic correlations were consistently lower than the respective genetic correlations.

\section{Table 3}

Heritabilities, genetic correlations and phenotypic correlations (in parentheses) of udder score (US), milk yield (MY), fat percentage (FC) and protein percentage (PC) for pairs of test days and lactation in Sfakia dairy sheep (heritabilities are reported for pairs of test days with the same pair of figures) (Heritabilitätswerte, genetische und phänotypische (in Klammern) Korrelationen der Euterform (US), der Milchmenge (MY), des Fettgehalts (FC) und des Eiweißgehalts (PC) für Testtagspaare beim Sfakia Milchschaf (Heritabilitätswerte sind für Paare mit gleichen Nummern ausgewiesen))

\begin{tabular}{ccccc}
\hline & & & Trait & PC \\
\hline Pairs of test days & US & MY & FC & 0.44 \\
11 & $0.17^{1}$ & 0.41 & 0.32 & $0.99(0.49)$ \\
13 & $0.55^{2}(0.13)$ & $0.78(0.48)$ & $0.99(0.55)$ & $0.89(0.38)$ \\
14 & $0.56(0.20)$ & $0.76(0.43)$ & $0.90(0.45)$ & $0.85(0.34)$ \\
22 & $0.57(0.21)$ & $0.71(0.42)$ & $0.79(0.38)$ & 0.54 \\
23 & 0.24 & 0.46 & 0.40 & $0.90(0.52)$ \\
24 & $0.55(0.23)$ & $0.88(0.55)$ & $0.94(0.43)$ & $0.85(0.45)$ \\
33 & $0.54(0.11)$ & $0.79(0.48)$ & $0.85(0.39)$ & 0.54 \\
34 & 0.19 & 0.47 & 0.46 & $0.95(0.55)$ \\
44 & $0.54(0.18)$ & $0.96(0.57)$ & $0.97(0.49)$ & 0.55 \\
Lactation & 0.20 & 0.45 & 0.52 & 0.52 \\
\hline
\end{tabular}

${ }^{1}$ Standard errors of heritability estimates are in the range of $0.04-0.06$

${ }^{2}$ Standard errors of genetic correlation estimates are in the range of $0.24-0.28$

Heritability estimates of US were comparable to those reported in the literature. Udder morphology traits can be classified into two categories: those related to udder size (depth, width, length and circumference) and those related to teat measurements (length, diameter and angle). Udder size measurements are reported to have heritabilities of 0.16 to 0.48 (MAVROGENIS et al., 1988; CHARON, 1990); FERNANDEZ et al., 1997). Heritabilities of teat measurements are in the range of 0.18 to 0.68 (GOOTWINE et al., 1980; MAVROGENIS et al., 1988; CHARON, 1990; FERNANDEZ et al., 1997). Udder shape is reported to have heritability of 0.24 to 0.55 (FERNANDEZ et al., 1997; CARTA et al., 1998). The various udder size measurements are moderately to highly genetically correlated (CHARON et al., 1990; FERNANDEZ et al., 1997). This is also valid for the teat measurements (PAPACHRISTOPHOROU and MAVROGENIS, 1981; MAVROGENIS et al., 1988; 
CHARON, 1990; FERNANDEZ et al., 1997). Furthermore, udder size measurements are found to be correlated with teat measurements (PAPACHRISTOPHOROU and MAVROGENIS, 1981; MAVROGENIS et al., 1988; CHARON, 1990; FERNANDEZ et al., 1997) implying that selection for improvement of one or some traits would result in improvement of others. Furthermore, udder shape as a global trait of udder morphology is also correlated to udder and teat measurements. FERNANDEZ et al. (1997) concluded that optimal udder shape, for machine milking, could be easily attained as this trait is strongly positively genetically correlated with udder placement and attachment and moderately with teat size, in Spanish Churra ewes. CHARON (1990) proposed the use of (transversal) circumference of the udder, which includes the width and the depth of the udder, as an index of udder volume and the teat diameter, an also important trait not only for machine-milking, but for lamb rearing as well, in Polish Lowland ewes. DE LA FUENTE et al. (1996) proposed, instead of selecting on udder shape, the calculation of an index, in which udder attachment and teat placement would have a positive sign and udder depth and teat size a negative one, in Spanish Churra ewes. This suggestion, however, was based on merely phenotypic and not on genetic grounds.

Table 4

Genetic and phenotypic correlations (in parentheses) between udder score (US), milk yield (MY), fat percentage (FC) and protein percentage (PC) in the four test days and lactation in Sfakia dairy sheep (Genetische und phänotypische (in Klammern) Korrelationen zwischen der Euterform (US), der Milchmenge (MY), des Fettgehalts (FC) und des Eiweißgehalts (PC) an vier Testtagen beim Sfakia Milchschaf)

\begin{tabular}{cccccc}
\hline & \multicolumn{5}{c}{ Test day } \\
\cline { 2 - 5 } Pairs of traits & 1 & 2 & 3 & 4 & Lactation \\
\hline US-MY & $-0.03^{1}(-0.01)$ & $-0.05(-0.02)$ & $-0.02(0.0)$ & $-0.06(-0.02)$ & $-0.06(-0.03)$ \\
US-FC & $-0.07(0.02)$ & $-0.03(-0.03)$ & $-0.04(-0.2)$ & $-0.04(-0.02)$ & $-0.04(0.03)$ \\
US-PC & $-0.05(0.01)$ & $-0.03(0.0)$ & $-0.02(0.0)$ & $-0.03(0.1)$ & $-0.06(0.02)$ \\
MY-FC & $-0.52(-0.34)$ & $-0.48(-0.32)$ & $-0.44(-0.28)$ & $-0.37(-0.19)$ & $-0.45(-0.26)$ \\
MY-PC & $-0.50(-0.29)$ & $-0.46(-0.24)$ & $-0.45(-0.22)$ & $-0.44(-0.21)$ & $-0.46(-0.28)$ \\
FC-PC & $0.80(0.45)$ & $0.78(0.43)$ & $0.72(0.41)$ & $0.72(0.40)$ & $0.76(0.45)$ \\
\hline
\end{tabular}

${ }^{1}$ Standard errors of genetic correlation estimates are in the range of $0.25-0.28$

Table 4 reports the genetic and phenotypic correlations of the various traits over the four test days. The genetic correlation between production traits and US was found, in test days as well as in lactation, almost nil (-0.02 to -0.07$)$ and of negative sign. These results are in agreement with those of Table 2, showing that means of milk traits, except for PC, are not statistically different between the two udder types. Genetic correlation between MY - FC was highly negative, ranging from $-0.52\left(1^{\text {st }}\right.$ test day) to -0.37 ( $4^{\text {th }}$ test day). Genetic correlation between MY and PC was also negative, from 0.44 to -0.50 , while genetic correlation between $\mathrm{PC}$ and FC was highly positive, in the magnitude of 0.72 to 0.80 . In the present study, the genetic correlation between US MY, US- FC and US - PC was found very low, implying that selection on yield traits is not expected to affect the udder morphology. FERNANDEZ et al. (1997) reported negative genetic correlations of moderate magnitude (from -0.02 to -0.34 ) between udder conformation and yield traits. They concluded that in Churra ewes, selection for increased milk yield might worsen udder morphology for machine milkability as a result of increased udder depth and reduced teat verticality. On the contrary, CARTA et al. (1998) reported a positive, moderate (0.27) genetic correlation between udder scoring and milk yield in the Sarda dairy sheep. The authors concluded that selection 
for modifying udder morphology, particularly teat placement and cistern height traits, with simultaneous improvement of milk yield could be efficient.

Heritability estimates of test day records for MY were clearly higher than those reported in the literature. In Lacaune dairy ewes, BARILLET et al. (1998) reported heritabilities between 0.19 ( $1^{\text {st }}$ test day) to 0.30 ( $2^{\text {nd }}$ test day), between 0.19 ( $1^{\text {st }}$ test day) to 0.41 ( $4^{\text {th }}$ test day) and between $0.45\left(1^{\text {st }}\right.$ test day) to 0.51 ( $3^{\text {rd }}$ test day) for test day MY, FC and PC, respectively. Lactation heritabilities were $0.35,0.49$ and 0.54 for MY, FC and PC, respectively. In Spanish Churra ewes, BARO et al. (1994), reported heritabilities for test day milk yield and protein percentage of 0.34 and 0.13 , respectively. MAVROGENIS et al. (1998) estimated heritability of 0.26 for test day milk yield in Chios sheep. Test day milk yield is reported to be genetically correlated with FC in the magnitude of -0.20 ( $1^{\text {st }}$ test day) to -0.85 ( $4^{\text {th }}$ test day) (BARILLET et al., 1998). The respective correlation between MY - PC is also of high magnitude ranging from -0.43 ( $3^{\text {rd }}$ test day) to -0.79 ( $4^{\text {th }}$ test day) (BARILLET et al., 1998). Lactation genetic correlations between MY-FC and MY-PC were -0.42 and -0.51 , respectively. On the contrary, BARO et al. (1994) found no genetic correlation between MY - PC. EL-SAIED et al. (1998) reported a genetic correlation of -0.27 between milk yield and protein percentage in Spanish Churra ewes.

Given the high genetic correlations between test day MYs, selection on early records is expected to result in increased lactation milk yield for Sfakia ewes. Selection of Sfakia ewes on merely milk yield, however, is expected to lower fat and protein percentages. Lower percentages of milk fat and protein may have an impact on the production efficiency of the various dairy products (cheese, yoghurt, etc) prepared from ewes' milk and therefore are of major economic importance for the regional producers. Such a problem could be overcome by using independent culling levels for milk yield and milk percentages by applying restriction selection indices (KOMINAKIS et al., 1999). Given the high, positive genetic correlation between FC and PC selection could concentrate on PC only, because this trait showed higher heritability than FC. When milk percentages are intended to retain unchanged, efficiency of selection is then dependent on how udder morphology and milk yield are weighed in the aggregate breeding value. In a future study, a method for properly weighing the traits US, MY, FC and PC in the selection index is going to be presented.

\section{Conclusion}

Selection for udder shape in an attempt to adapt the Sfakia breed for machine milking is expected to be efficient. Further research is needed to define the udder traits and linear scales for use as selection criteria for milkability of the breed. Selection on merely milk yield is not expected to result in correlated responses for udder shape but is expected to substantially lower the fat and protein percentages of the milk. Furthermore, selection on early records is expected to result in increased lactation milk yield for Sfakia ewes. Selection could concentrate on udder score, daily milk yield and protein percentage by properly weighing these traits in the selection index.

\section{References}

BARILLET, F.; RUPP, R.; MIGNON-CRASTEAU, S.; ASTRUC, J. M.; LACQUIN, M.; LAGRIFFOUL, G.: Genetic analysis for mastitis resistance and somatic cell score in French Lacaune dairy sheep, In: Barillet and Zervas (Eds) Proceedings of the $6^{\text {th }}$ International Symposium on Milking of Small Ruminants, Athens, Greece, 1998, pp. 393-399 
BARO, J.A.; CARRIEDO, J.A.; SAN PRIMITIVO, F.:

Genetic parameters of test day measures for somatic cell count, milk yield and protein percentage of milking ewes. J. Dairy Sci., 77 (1994), 2658 - 2662.

CARTA, A.; SANNA, S.R.; RUDA, G.; CASU, S.:

Genetic aspects of udder morphology in Sarda primiparous ewes. In: Barillet and Zervas (Eds) Proceedings of the $6^{\text {th }}$ International Symposium on Milking of Small Ruminants, Athens, Greece, 1998, pp. 363-368.

CASU, S.; BARILLET, F.; CARTA, R.; SANNA, S.:

Amélioration génétique de la forme de la mamelle de la brebis Sarde en vue de la traite mécanique: résultats préliminaires. In Proceedings of the $4^{\text {th }}$ International Symposium Machine Milking Small Ruminants, Tel-Aviv, Israel, 1989, p.104.

CASU, S.; CARTA, R.; RUDA, G.:

Morphologie de la mamelle et aptitude à la traite mécanique de la brebis Sarde, In Proceedings of $3^{\text {rd }}$ International Symposium Machine Milking Small Ruminants, Valladolid, Spain, 1983, p.592.

CHARON, K. M.:

Genetic parameters of the morphological traits of sheep udder. World Rev. Anim. Prod. 25 (1990), 73 76.

DE LA FUENTE, L.F.; FERNANDEZ, G.; SAN PRIMITIVO, F.:

A linear evaluation system for udder traits of dairy ewes. Livest. Prod. Sci. 45 (1996), 171 - 178.

EL-SAIED, U.M.; CARRIEDO, J.A.; DE LA FUENTE, L.F; SAN PRIMITIVO, F.:

Genetic and environmental correlations between somatic cell counts, milk yield and protein percentage in milking ewes. In: Barillet and Zervas (Eds) Proceedings of the $6^{\text {th }}$ International Symposium on Milking of Small Ruminants, Athens, Greece, 1998, pp. 400-405.

FERNANDEZ, G.; ALVEREZ, P.; SAN PRIMITIVO, F.; DE LA FUENTE, L. F.: Factors affecting variation of udder traits of dairy ewes. J. Dairy Sci. 78 (1995), $842-849$.

FERNANDEZ, G.; BARO, J.A.; DE LA FUENTE, L.F.; SAN PRIMITIVO, F.: Genetic parameters for linear udder traits in dairy ewes. J. Dairy Sci. 80 (1997), $601-605$

GOOTWINE, E.; ALEF, B.; GADESH, S.:

Udder conformation and its heritability in the Assaf (Awassi x East Friesian) cross of dairy sheep in Israel. Ann. Génét. Sél. Anim. 12 (1980), 9 - 13.

KOMINAKIS, A.; VOLANIS, M.; ROGDAKIS, E.:

Genetic and phenotypic parameters of milk yield in Sfakia sheep, $15^{\text {th }}$ Scientific Meeting of the Hellenic Zootechnical Society, 3 - 5 Nov. 1999, Chania, Greece.

KUKOVICS, S.; NAGY, A.; MOLNAR, A.; ABRAHAM, M.:

Relationships among udder scores and relative udder size and milk production as well as their changes during the successive lactations, In S. Kukovics (Publ) Proceedings of the $5^{\text {th }}$ International Symposium Milking Small Ruminants, Budapest, Hungary, 1993, p. 40.

LABUSSIERE, J.; DOTCHEWSKI, D.; COMBAUD, J, F.:

Charactéristiques morphologiques de la mamelle de brebis Lacaune. Méthodologie pour l'obtention des données. Relations avec l'apritude à la traite. Ann. Zootech. 30 (1981), 115 - 136.

LABUSSIERE, J.:

Review of physiological and anatomical factors influencing the milking ability of ewes and the organisation of milking. Livest. Prod. Sci. 18 (1988), $253-274$.

MAHLER, X.; VRAYLA-ANESTI, F.:

An evaluation of milk yield and milking ability in French Rouge de l'Ouest ewes. Small Rum. Res. 13 (1994), $1-8$

MAVROGENIS, A.P.; KOUMAS, A.; GAVRIELIDIS, G.:

The inheritance of somatic cell counts (index of mastitis) in Chios sheep. In: Barillet and Zervas (Eds) Proceedings of the $6^{\text {th }}$ International Symposium on Milking of Small Ruminants, Athens, Greece, 1998, pp. 389-392

MAVROGENIS, A.P.; PAPACHRISTOPHOROU, C.; LYSANDRIDES, P.H.; ROUSHIAS, A.:

Environmental and genetic factors affecting udder characteristics and milk production in Chios sheep. Génét. Sel. Evol. 20 (1988), 477-488.

MEYER, K.:

DFREML, User notes, version 3.0a, 1997.

PAPACHRISTOPHOROU, C.; MAVROGENIS, A.P.:

Udder characteristics of Chios sheep and their relation to milk production and machine milking, Technical paper 20 (1981) 1-9, Agric. Res. Inst., Nicosia, Cyprus.

PAPADOPOULOS, O.:

Die Schafschläge der Insel Kreta (Das Sitiaschaf und das Sphakiaschaf). Zeitschrift für Züchtung B: Tierzüchtung und Züchtungsbiologie 35 (1936), 107-136 
SAGI, R.; MORAG, M.:

Udder conformation, milk yield and milk fractionation in the dairy ewe. Ann. Zootech. 23 (1974), 185 192.

SAGI, R.:

Udder support as a means for improving milk fractionation in dairy ewes. Ann. Zootech. 27 (1978), 347 -353 .

SAS:

User notes, Version 6, $4^{\text {th }}$ ed., SAS Institute, Inc., Cary, NC, 1992.

VOLANIS, M.; TZERAKIS, K.:

Study of the Sfakia sheep breed. I. Reproductive and productive characteristics of the ewelambs. Anim. Sci. Rev., 23 (1997a) 5-28 (in Greek with English summary).

VOLANIS, M.; TZERAKIS, K.:

Study of the Sfakia sheep breed. II. Reproductive characteristics of the ewes and growth characteristics of the lambs. Anim. Sci. Rev., 24 (1997b) 5 - 20 (in Greek with English summary).

VOLANIS, M.; TZERAKIS, K.:

Study of the Sfakia sheep breed. III. Milk production. Anim. Sci. Rev., 24 (1997c) 21 - 38 (in Greek with English summary).

Received: $2000-12-22$

Accepted: 2001-12-06

Authors addresses

Dr. MANOUSOS VOLANIS

National Agricultural Research Foundation,

Chania, 73100, Greece

Dr. ANTONIOS KOMINAKIS, Prof. Dr. EMMANOUEL ROGDAKIS

Department of Animal Breeding and Husbandry, Faculty of Animal Science, Agricultural University of Athens,

Iera Odos 75, 11855, Athens, Greece

e-mail : acom@aua.gr 